\title{
REPRESENTAÇÃO DO CAMPO DE GRAVIDADE TERRESTRE NO SUL DA PLACA DA ÁFRICA
}

\author{
Ahmed Mohammad Abdel Meguid \\ Orientador: Dr. Eder Cassola Molina (IAG-USP) \\ 97 p. + 17 apêndices - Dissertação (Mestrado) - Defesa 22.06.2005
}

RESUMO. Um novo modelo digital do campo de gravidade terrestre é apresentado neste trabalho, representando a anomalia ar-livre e a anomalia de altitude na parte sul da placa da África. Um total de 12203 observações gravimétricas terrestres e 5486 pontos de anomalias ar-livre calculadas a partir do mais recente modelo geopotencial fornecido pela missão GRACE foram utilizados no processo de colocação por mínimos quadrados, com a finalidade de realizar a representação do campo gravidade na região. Um novo algoritmo computacional foi escrito, como aplicação de Matlab, para calcular as covariâncias a partir dos dados observados e para implementar a técnica de colocação por mínimos quadrados. A aplicação do método de colocação por mínimos quadrados seguiu as instruções detalhadas por Mortiz (1980), assumindo um erro constante de 3 mGal aos pontos de dados da anomalia ar-livre. Foram realizados vários testes para definir os parâmetros utilizados no cálculo, tais como 0 raio da busca e 0 intervalo entre os pontos de cálculo. 0 raio de busca assim escolhido foi de $0,5^{\circ}$, que é compatível com a componente determinística removida expandindo 0 modelo EGM96 até grau e ordem 360. 0 intervalo entre os pontos de cálculo foi definido a ser de $0,1^{\circ} .0$ modelo obtido foi então comparado com o conjunto de dados disponíveis na região e com os modelos do campo de gravidade existentes, e mostrou boa concordância com eles. A resolução espacial do modelo é adequada para que ele seja utilizado em estudos geofísicos regionais, tais como na investigação de propriedades mecânicas da litosfera.

ABSTRACT. This work presents a new digital gravity field model, representing the free air anomaly and the height anomaly in the southern part of the African plate. A total of 12,203 gravity observations, together with 5,486 free air data points calculated after the most recent geopotential model calculated by GRACE mission team, were used in the process of Least Squares Collocation (LSC) in order to obtain the present representation. A new computer algorithm was written, as a Matlab application, to calculate the covariance using the observed gravity data and to implement the method of Least Squares Collocation. The LSC method was applied as described by Moritz (1980) assuming a constant standard error of 3 mGal to the free air data points. Various tests were made in order to define the parameters used in the calculation process, such as the search radius and the interval between the points of calculation. The search radius was chosen to be of $0.5^{\circ}$, which is quite compatible with the deterministic component removed expanding the Earth Gravity Model EGM96 to degree and order 360. The interval of calculation was defined to be of $0.1^{\circ}$. The resultant model was compared with the available data set of the region and with the existent geopotencial models and shown a good concordance with them. The obtained model is, adequated to be used in regional geophysical studies, such as the investigations of the mechanical properties of the lithosphere. 